\title{
Case for diagnosis. Erythroderma as manifestation of hypereosinophilic syndrome*
}

\author{
Maira Renata Merlotto ${ }^{1}$ \\ Delmo Sakabe ${ }^{3}$
}

DOI: http:/ / dx.doi.org/10.1590/abd1806-4841.20187419

\section{CASE REPORT}

Patient was a 36-year-old Brazilian male physician of Japanese descent with no comorbidities or atypical signs. Six years previously he presented intermittent erythematous papules on the trunk and face, in addition to pruritus aggravated by heat or alcohol intake. Six months previously he evolved with erythroderma, treated with cyclosporine $(3 \mathrm{mg} / \mathrm{kg} / \mathrm{d})$, hydration, and topical corticosteroids, with partial improvement. On physical examination: erythroderma, facial infiltration, and infiltrated erythematous plaques (mainly cubital and popliteal), xeroderma, thickening of the greater

\author{
Lucas Oliveira Cantadori ${ }^{2}$ \\ Hélio Amante Miot ${ }^{1}$
}

auricular, fibular, radial, and ulnar nerves with reduced strength in hands (Figure 1). Anatomical pathology of the skin revealed acanthosis, spongiosis, and superficial lymphocytic infiltrate with eosinophils (Figure 2). Complete blood count: eosinophilia 2,812U/ $\mu \mathrm{L}$; $\operatorname{IgE~1,164~kU/L~(ULN~114kU/L),~and~DHL~596U/L~(ULN~225U/L).~}$ Ultrasound of the wrists showed thickening of the median nerve with normal morphology of the carpal tunnel. Normal echocardiogram, and abdominal tomography showed periaortic lymph nodes slightly increased in number.
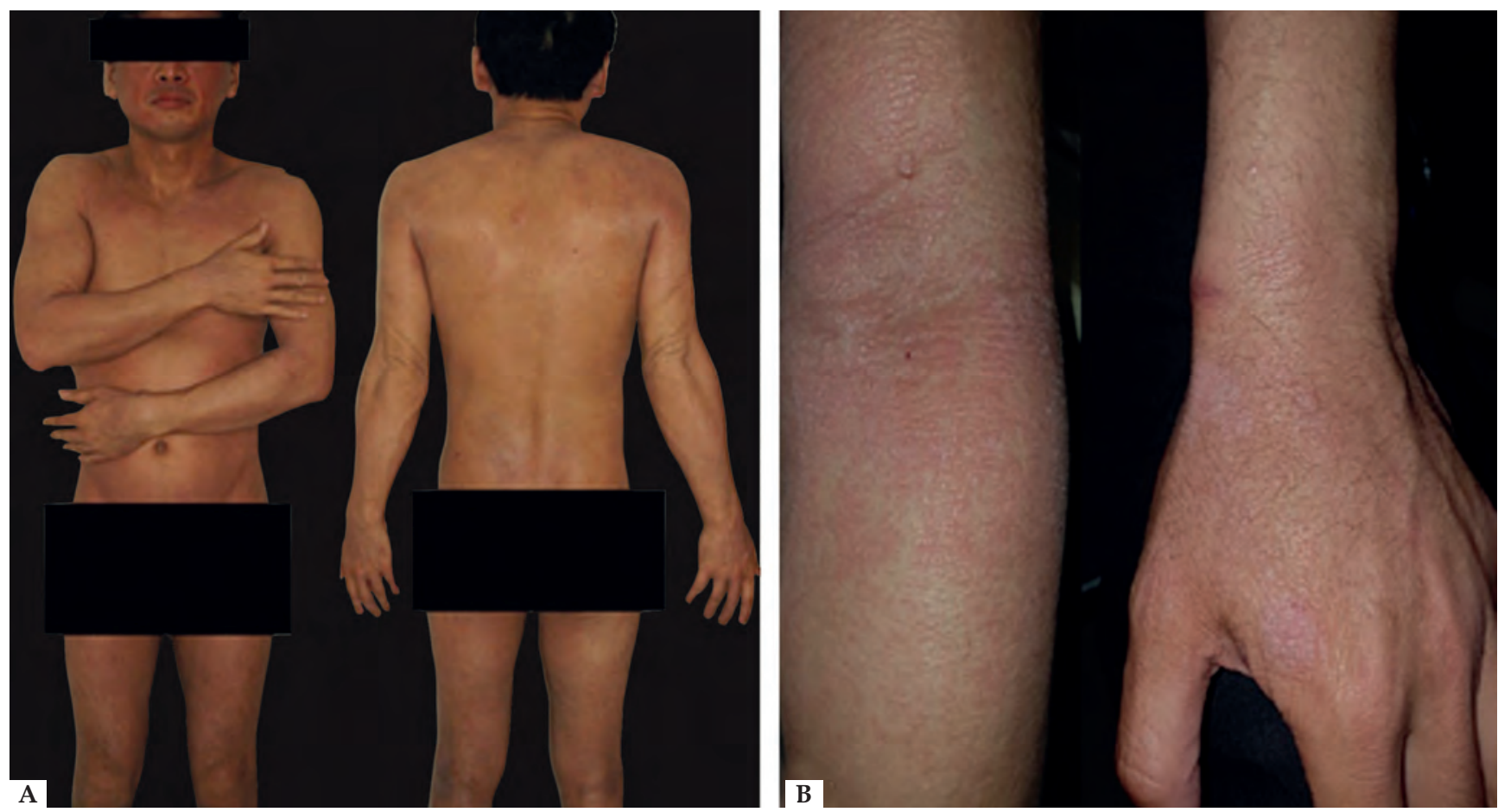

FIgURE 1: A. Erythroderma with facial infiltration. B. Detail of infiltrated plaques on limbs and antecubital region

Received 10 July 2017.

Accepted 07 December 2017

* Work conducted at Hospital das Clínicas da Faculdade de Medicina de Botucatu, Universidade Estadual Paulista (FMB-Unesp), Botucatu (SP), Brazil. Financial support: None. Conflict of interest: None.

Department of Dermatology, Faculdade de Medicina de Botucatu, Universidade Estadual Paulista (FMB-Unesp), Botucatu (SP), Brazil.

2 Discipline of Hematology, Department of Clinical Medicine, Faculdade de Medicina de Botucatu, Universidade Estadual Paulista (FMB-Unesp), Botucatu (SP), Brazil.

3 Department of Surgery, Pontifícia Universidade Católica de São Paulo (PUC-Sorocaba), Sorocaba (SP), Brazil.

MAILING ADDRESS:

Hélio Amante Miot

E-mail: heliomiot@fmb.unesp.br 

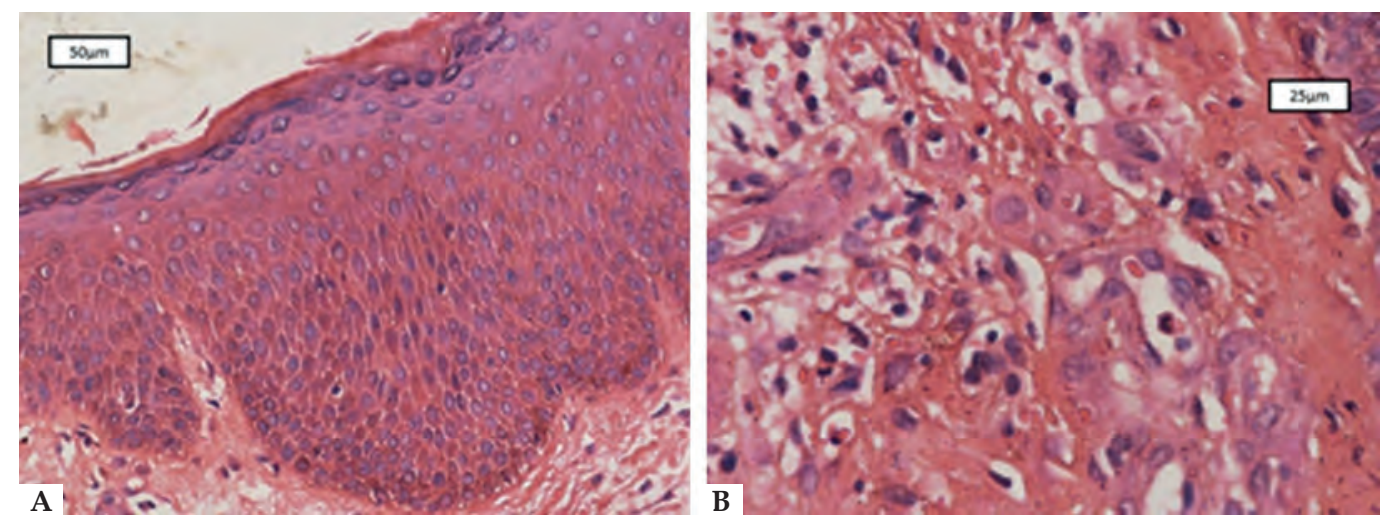

FIGURE 2: Histopathology

(Hematoxylin \& eosin)

A. Mild acanthosis and spongiosis $(\mathrm{X} 20)$. B. Edema of the upper dermis and lymphocytic infiltration with eosinophils (X40)

\begin{tabular}{|c|c|c|}
\hline Original diagnostic criteria, Chusid et al. ${ }^{1}$ & $\begin{array}{l}\text { Modification to diagnostic criteria for } \\
\text { HES by Simon et al. }{ }^{1}\end{array}$ & Comments \\
\hline $\begin{array}{l}\text { 1. Peripheral eosinophilia }>1500 / \mu \mathrm{L} \text { per- } \\
\text { sisting for more than six consecutive } \\
\text { months. }\end{array}$ & $\begin{array}{l}\text { Persistent eosinophilia. Arbitrary value of } \\
1500 / \mu \mathrm{L} \text { is not mandatory }\end{array}$ & $\begin{array}{l}\text { Presence of tissue infiltration with eosino- } \\
\text { phils leading to tissue damage is more im- } \\
\text { portant than setting a laboratory value }\end{array}$ \\
\hline $\begin{array}{l}\text { 2. Rule out secondary causes of hypereosino- } \\
\text { philia after extensive clinical workup }\end{array}$ & $\begin{array}{l}\text { Peripheral eosinophilia should be con- } \\
\text { firmed, but its persistence for more than } \\
\text { six months is no longer mandatory }\end{array}$ & $\begin{array}{l}\text { In symptomatic patients with confirmed } \\
\text { eosinophilia and organ involvement, pro- } \\
\text { ceed to treatment to prevent organ damage; } \\
\text { any duration is significant, even less than } \\
\text { six months }\end{array}$ \\
\hline $\begin{array}{l}\text { 3. Symptomatic organ involvement second- } \\
\text { ary to hypereosinophilia }\end{array}$ & $\begin{array}{l}\text { Signs and/or symptoms of organ in- } \\
\text { volvement are not mandatory }\end{array}$ & $\begin{array}{l}\text { At the time of diagnosis, it is very difficult } \\
\text { to predict evolution in asymptomatic pa- } \\
\text { tients. Some may be asymptomatic at first } \\
\text { evaluation and either remain asymptomat- } \\
\text { ic or evolve due to tissue damage or organ } \\
\text { involvement }\end{array}$ \\
\hline
\end{tabular}

\begin{tabular}{|c|c|c|c|}
\hline Subtypes & Characteristics & Treatment & Prognosis \\
\hline $\begin{array}{l}\text { Myeloproliferative } \\
\text { (HES-M) }\end{array}$ & $\begin{array}{l}\text { Tyrosine kinase activation by } \\
\text { FIP1L1 and PDGFRA gene } \\
\text { fusion, eosinophilia due to } \\
\text { clonal proliferation of myeloid } \\
\text { precursors }\end{array}$ & $\begin{array}{l}\text { Little response to systemic corticoste- } \\
\text { roids. More response to hydroxyurea, } \\
\text { interferon, and chemotherapy - busulfan, } \\
\text { chlorambucil, and vincristine. } \\
\text { Imatinib is the drug of choice for patients } \\
\text { with positive F/P mutation }\end{array}$ & $\begin{array}{l}\text { Survival depends on severity } \\
\text { of tissue injury, especially the } \\
\text { degree of cardiac involvement. } \\
\text { Risk of development of malign } \\
\text { myeloproliferative disease }\end{array}$ \\
\hline Idiopathic (HES-I) & $\begin{array}{l}\text { T-cell polyclonal expansion un- } \\
\text { regulated production of Th2 cy- } \\
\text { tokines (IL-5 and/or IL-3) }\end{array}$ & $\begin{array}{l}\text { Good response to systemic corticosteroids } \\
\text { aloneorincombination with hydroxyurea, } \\
\text { mepolizumab, interferon- } \alpha \text {, or tofacitinib }\end{array}$ & $\begin{array}{l}\text { Chronic, benign condition with } \\
\text { indolent clinical course. } \\
\text { Occasional development of lym- } \\
\text { phoma }\end{array}$ \\
\hline $\begin{array}{l}\text { Lymphocytic/Sec- } \\
\text { ondary (HES-L) }\end{array}$ & $\begin{array}{l}\text { Polyclonal expansion of anom- } \\
\text { alous T-cells (CD3-CD4+) and } \\
\text { unregulated production of Th2 } \\
\text { cytokines (especially IL-5) }\end{array}$ & $\begin{array}{l}\text { Adequate control with systemic corticos- } \\
\text { teroids alone or in combination with hy- } \\
\text { droxyurea, mepolizumab, or tocilizumab }\end{array}$ & $\begin{array}{l}\text { Chronic recurrent. } \\
\text { Occasional development of lym- } \\
\text { phoma }\end{array}$ \\
\hline
\end{tabular}

\section{DISCUSSION}

Hypereosinophilic syndrome (HES) is characterized by persistently elevated peripheral eosinophil count $(>1,500 / \mu \mathrm{L})$ associated with symptomatic organ involvement, excluding secondary causes of eosinophilia (Chart 1). ${ }^{1}$ It is classified as myeloproliferative (HES-M), secondary or reactive (HES-L), and idiopathic (HES-I) (Chart 2) ${ }^{2}$

HES is a rare disease $(5,000$ cases/year in the United States of America), potentially fatal, and the organs most frequently in- volved are skin, lungs, intestine, heart, kidneys, eyes, and peripheral nervous system. The most serious complication is cardiac, which should be investigated in all cases. In adults, the syndrome is more common in males (ratio 9:1), and mean age at onset is 50 years. Investigation of organ involvement and sub-classification are decisive for treatment and prognosis., 
Cutaneous manifestations of HES require differential diagnosis with urticaria, pruritus sine materia, mycosis fungoides, cutaneous adverse drug reactions, contact dermatitis, and atopic dermatitis. Dermatologists should be alert to pruritic erythematous papules, urticaria, angioedema, dermographism, oral and genital ulcers, centrifugal annular erythema, acral bullae, and erythroderma. Histopathologic examination of the skin lesion is usually nonspecific, with viable eosinophilic infiltration. ${ }^{4-7}$

In an endemic country like Brazil, a presentation with polyneuropathy requires ruling out leprosy, which is unlikely in this case because of the pruritus and histology.

In this case, treatment began with prednisone $1 \mathrm{mg} / \mathrm{kg} /$ day, with important improvement in the skin lesions, eosinophilia (580/ $\mu \mathrm{L}$ ), and pruritus after 30 days. Bone marrow biopsy did not show neoplastic infiltration, FISH cytogenetic test did not reveal deletion or translocation of the FIP1L1 and PDGFRA genes, JAK2 muta- tion was negative, and immunophenotyping did not show clonal lymphocyte populations. Adjuvant therapy with hydroxyurea was scheduled in conjunction with the Department of Hematology.

The case was classified as HES-I based on the absence of lymphocytic phenotypical abnormalities or genetic alterations. Presence of peripheral neuropathy, absence of atopic signs, and worsening of the clinical picture with alcohol intake were characteristic. High IgE levels, good response to corticosteroid therapy, and low serum tryptase level and eosinophil count $<100,000 / \mu \mathrm{L}$ are associated with better prognosis. Therapeutic success in HES-I has been reported with tofacitinib and mepolizumab., , $8-10^{-10}$

Diagnosis of HES is often delayed due to its pleomorphic dermatological manifestations and insidious evolution. It is thus crucial that in all cases of erythroderma, HES should be considered as a differential diagnosis. ${ }^{6,7}$

\begin{abstract}
Hypereosinophilic syndrome is defined as persistent eosinophilia ( $>1500 / \mu \mathrm{L}$ for more than six months) associated with organ involvement, excluding secondary causes. It is a rare, potentially lethal disease that should be considered in cutaneous conditions associated with hypereosinophilia. We report a case of erythroderma as a manifestation of hypereosinophilic syndrome. A 36-year-old male with no comorbidities presented progressive erythroderma, pruritus, peripheral neuropathy, and eosinophilia in the previous seven months. No mutations were found in FIP1L1/PDGFRA. Patient experienced rapid remission in response to oral prednisone and hydroxyurea. Cutaneous manifestations may be the only evidence of hypereosinophilic syndrome. Genotyping excludes myeloproliferative disease, thereby orienting treatment and prognosis.
\end{abstract}

Keywords: Eosinophilia; Polyneuropathies; Dermatitis, Exfoliative

\section{REFERENCES}

1. Simon HU, Rothenberg ME, Bochner BS, Weller PF, Wardlaw AJ, Wechsler ME, et al. Refining the definition of hypereosinophilic syndrome. J Allergy Clin Immunol. 2010;126:45-9.

2. Valent P, Klion AD, Horny HP, Roufosse F, Gotlib J, Weller PF, et al. Contemporary consensus proposal on criteria and classification of eosinophilic disorders and related syndromes. J Allergy Clin Immunol. 2012;130:607-612.e9.

3. Hsieh FH. Hypereosinophilic syndrome. Ann Allergy Asthma Immunol. 2014;112:484-8

4. Plötz SG, Hüttig B, Aigner B, Merkel C, Brockow K, Akdis C, et al. Clinical overview of cutaneous features in hypereosinophilic syndrome. Curr Allergy Asthma Rep. 2012;12:85-98.

5. Kazmierowski JA, Chusid MJ, Parrillo JE, Fauci AS, Wolff SM. Dermatologic manifestations of the hypereosinophilic syndrome. Arch Dermatol. 1978;114:531-5.
6. Mahajan VK, Singh R, Mehta KS, Chauhan PS, Sharma S, Gupta M, et al. Idiopathic hypereosinophilic syndrome: a rare cause of erythroderma. J Dermatol Case Rep. 2014;8:108-14.

7. Abdulsalam MS, Ghanta HC, Pandurangan P, Menon M, Jacob SS. A Case of Erythroderma Secondary to Hypereosinophilia. J Clin Diagn Res. 2016;10:0D15-6.

8. King B, Lee Al, Choi J. Treatment of Hypereosinophilic Syndrome with Cutaneous Involvement with the JAK Inhibitors Tofacitinib and Ruxolitinib. J Invest Dermatol. 2017; 137:951-954.

9. Schwartz LB, Sheikh J, Singh A. Current strategies in the management of hypereosinophilic syndrome, including mepolizumab. Curr Med Res Opin. 2010;26:1933-46.

10. Noh HR, Magpantay GG. Hypereosinophilic syndrome. Allergy Asthma Proc. 2017:38:78-81.

$\begin{array}{ll}\text { Maira Renata Merlotto } & \text { (D) ORCID 0000-0002-8918-5640 } \\ \text { Lucas Oliveira Cantadori } & \text { (D) ORCID 0000-0003-0436-1842 }\end{array}$

\author{
Delmo Sakabe \\ Hélio Amante Miot
}

ORCID 0000-0003-0181-0905

ORCID 0000-0002-2596-9294

How to cite this article: Merlotto MR, Cantadori LO, Sakabe D, Miot HA. Case for diagnosis. Erythroderma as manifestation of hypereosinophilic syndrome. An Bras Dermatol. 2018;93(3):451-3. 